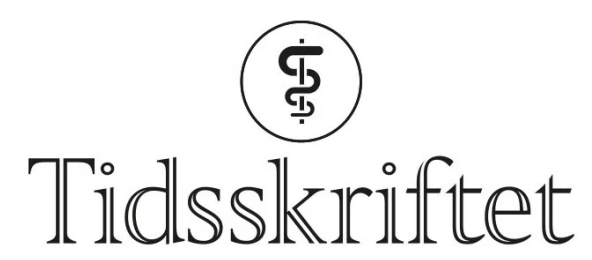

DEN NORSKE LEGEFORENING

\title{
Blærer til besvær
}

\author{
ANMELDELSER
}

GURI RøRTVEIT

Allmennmedisinsk forskningsenhet i Bergen

Uni helse

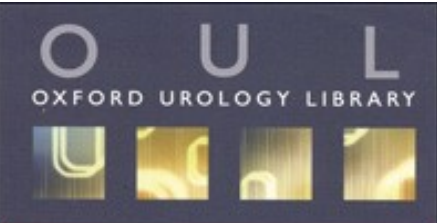

Overactive Bladder

Syndrome and

Urinary

Incontinence

Edited by

HASHIM HASHIM

PAUL ABRAMS

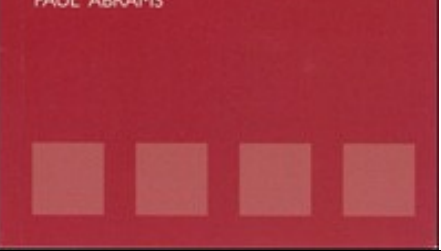

Hashim, Hashim

Abrams, Paul

Overactive bladder syndrome and urinary incontinence

84 s, ill. Oxford: Oxford University Press, 2011. Pris GBP 13

ISBN 978-0-19-959939-4

Dette er en liten håndbok om to hyppig forekommende tilstander: overaktiv blære-

syndrom og urinlekkasje. Begge tilstandene er både underdiagnostisert og underbehandlet. En enkel håndbok er derfor velkommen. Er så denne boken svaret? Både ja og nei. 
Boken er ment for så ulike grupper som urologer, gynekologer, medisinstudenter, geriatere, sykepleiere og allmennpraktikere. Da sier det seg selv at det kan være vanskelig å treffe alle. Bidragsyterne lykkes likevel med noen av sine ambisjoner.

Det er seks kapitler, som etterfølges av algoritmer for diagnostikk og behandling, både fra National Institute for Health and Clinical Excellence (NICE) og fra International Consultations (retningslinjer utviklet av det internasjonale fagmiljøet på feltet).

Først gir forfatterne en grei innføring i definisjon av begreper, noe som er nødvendig fordi det har skjedd en stor utvikling av terminologien de siste 15-20 årene, til nytte for både klinikere og forskere. Litt uheldig er det at redaktørene bruker sentrale begreper som «urinary incontinence» og «stress urinary incontinence» på tvetydige måter i kapitteloverskriftene.

Epidemiologikapitlet gjør nytten som bakgrunnsstoff, men er preget av at det ikke er skrevet av folk som forsker på feltet. Utvalget av referanser virker tilfeldig, og enkelte temaer er litt lemfeldig behandlet.

Kapitlet om teori og mekanismer bak overaktiv blære og stressinkontinens er nok i overkant detaljert for mange klinikere, men er kortfattet skrevet og kan derfor fungere som en oppslagsmulighet.

Det som volder meg mest hodebry med tanke på om jeg skal anbefale boken eller ikke, er kapitlet om diagnostikk. Til å være en bok med ambisjoner om å være kunnskapsbasert er det foruroligende at forfatterne anbefaler langt mer omfattende førstelinjediagnostikk enn det som er dokumentert nyttig. For allmennpraktikere er derfor listen over forventet diagnostikk altfor lang og kan fungere avskrekkende i stedet for motiverende. De kunnskapsbaserte algoritmene bakerst dokumenterer diskrepansen. Selvmotsigelser i en så liten bok burde være mulig å unngå.

De siste to kapitlene er delt opp i standardbehandling og behandling av kompliserte tilfeller - en hensiktsmessig inndeling. Blandingsinkontinens er beskrevet i begge kapitlene uten referanse til hverandre, og jeg savner en beskrivelse av mekaniske hjelpemidler som kan hindre lekkasje. Ellers gir forfatterne en lettfattelig og oppdatert oversikt over tilgjengelig behandling.

Utvalget av algoritmer til slutt er litt uklart. Det er dessuten et problem at lommehåndbokformatet gjør skriften i algoritmene så liten at kun medisinstudenter kan være i stand til å lese dem.

Oppsummert er boken oversiktlig, godt skrevet og hendig, men den er ikke helt pålitelig på alle felt. Tatt med en klype salt kan den fungere godt som en innføring i temaet.

Publisert: 12. juni 2012. Tidsskr Nor Legeforen. DOI: 10.4045/tidsskr.12.0418

(C) Tidsskrift for Den norske legeforening 2023. Lastet ned fra tidsskriftet.no 26. april 2023. 